\title{
, Nickel-Based Membrane Electrodes Enable High-Rate 2 Electrochemical Ammonia Recovery
}

\author{
3 Dianxun Hou, ${ }^{\dagger}$ Arpita Iddya, ${ }^{\ddagger}$ Xi Chen, ${ }^{\dagger}$ Mengyuan Wang, ${ }^{\S}$ Wenli Zhang, ${ }^{\prime \prime}$ Yifu Ding, ${ }^{\S}$ \\ ${ }_{4}$ David Jassby, ${ }^{\ddagger}$ and Zhiyong Jason Ren*,†잉 \\ $5{ }^{\dagger}$ Department of Civil, Environmental, and Architectural Engineering, University of Colorado Boulder, Boulder, Colorado 80303, \\ 6 United States \\ $7{ }^{\ddagger}$ Department of Civil and Environmental Engineering, University of California, Los Angeles, California 90095, United States \\ $8{ }^{8}$ Department of Mechanical Engineering, University of Colorado Boulder, Boulder, Colorado 80309, United States \\ 9 "Materials Science and Engineering, Physical Science and Engineering Division, King Abdullah University of Science and \\ 10 Technology, Thuwal 23955-6900, Kingdom of Saudi Arabia
}

12 ABSTRACT: Wastewater contains significant amounts of nitrogen that can be recovered and valorized as fertilizers and chemicals. This study presents a new membrane electrode coupled with microbial electrolysis that demonstrates very efficient ammonia recovery from synthetic centrate. The process utilizes the electrical potential across electrodes to drive $\mathrm{NH}_{4}{ }^{+}$ions toward the hydrophilic nickel top layer on a gas-stripping membrane cathode, which takes advantage of surface $\mathrm{pH}$ increase to realize spontaneous $\mathrm{NH}_{3}$ separation and recovery using the membrane electrode structure. Compared with a control configuration with conventionally separated electrode and hydrophobic membrane, the integrated membrane electrode showed $40 \%$ higher $\mathrm{NH}_{3}-\mathrm{N}$ recovery rate $\left(36.2 \pm 1.2 \mathrm{gNH}_{3}-\mathrm{N} / \mathrm{m}^{2}\right.$ / d) and $11 \%$ higher current density. The energy consumption was $1.61 \pm 0.03 \mathrm{kWh} / \mathrm{kgNH}_{3}-$ $\mathrm{N}$, which was $20 \%$ lower than the control and $70-90 \%$ more efficient than competing electrochemical nitrogen recovery processes $\left(5-12 \mathrm{kWh} / \mathrm{kgNH}_{3}-\mathrm{N}\right)$. Besides, the negative potential on membrane electrode repelled negatively charged organics and microbes thus reduced fouling. In addition to describing the system's performance, we explored the underlying mechanisms governing the reactions, which confirmed the viability of this process for efficient wastewater-ammonia recovery. Furthermore, the nickel-based membrane electrode showed excellent water entry pressure $(\sim 41 \mathrm{kPa})$ without leakage, which was much higher than that of PTFE/PDMS-based cathodes $(\sim 1.8 \mathrm{kPa})$. The membrane electrode also showed superb flexibility $\left(180^{\circ}\right.$ bend $)$ and can be easily fabricated at low cost $\left(<20 \$ / \mathrm{m}^{2}\right)$.

\section{INTRODUCTION}

30 Ammonia $\left(\mathrm{NH}_{3}\right)$ is an essential nutrient for global food 31 production and the second most common synthetic chemical 32 in the world. ${ }^{1}$ Ammonia is produced using the energy-intensive 33 Haber-Bosch process $\left(\sim 14 \mathrm{kWh} / \mathrm{kgNH}_{3}-\mathrm{N}\right)$, which ac34 counts for $1-2 \%$ of global energy consumption and $\sim 1.6 \%$ 35 of global $\mathrm{CO}_{2}$ emissions. ${ }^{2}$ However, due to incomplete 36 consumption and waste generation, significant amounts of 37 ammonia and other nitrogen compounds end up in waste38 water. This accounts for $\sim 30 \%$ of total nitrogen fertilizers. ${ }^{3,4}$ 39 Such high nitrogen loading not only adds treatment pressure 40 and costs to the wastewater infrastructure, ${ }^{5}$ it also leads to 41 eutrophication and other environmental problems. ${ }^{6,7}$ Current 42 mainstream treatment processes such as Anammox and 43 nitrification/denitrification do not recover nitrogen in a useful 44 form, instead converting nitrogen (ammonium and/or nitrate) 45 to $\mathrm{N}_{2}$, which consumes energy $\left(\sim 12.5 \mathrm{kWh} / \mathrm{kgNH}_{3}-\mathrm{N}\right)$ and 46 potentially releases greenhouse gas (i.e., $\mathrm{N}_{2} \mathrm{O}$ ) to the 47 atmosphere ${ }^{2,8}$ Moreover, the energy-intensive nutrient removal 48 processes contribute to greenhouse gas emission of $0.9 \mathrm{~kg} \mathrm{CO}$ per cubic meter of treated wastewater. ${ }^{2,9}$ Thus, recovering such 49 nutrients can be a promising strategy to benefit fertilizer and 50 food production, as well as greatly reduce the energy and 51 carbon footprint of the nitrogen cycle. ${ }^{2,10}$

A promising waste stream for nutrient recovery in 53 wastewater treatment is the centrate produced during 54 centrifugal sludge dewatering. ${ }^{5}$ The centrate is nutrient-rich 55 and contains high concentrations of ammonia nitrogen (>1100 56 $\left.\mathrm{mgNH}_{3}-\mathrm{N} / \mathrm{L}\right)$, total Kjeldahl nitrogen $(\mathrm{TKN},>1300 \mathrm{mgN} / 57$ $\mathrm{L}$ ), orthophosphate $\left(>200 \mathrm{mgPO}_{4}-\mathrm{P} / \mathrm{L}\right.$ ), and organics (up to 58 $2000 \mathrm{mg} / \mathrm{L}) .{ }^{11}$ Generally, wastewater treatment plants recycle 59 centrate back to the primary treatment units. However, the 60 small volume of centrate ( $<1 \%$ total volume) can contribute up 61 to $30 \%$ of nutrient loading, as well as elevated energy demand 62 and pipe scaling (from struvite), which leads to an increase in 63

Received: March 12, 2018

Revised: June 22, 2018

Accepted: June 25, 2018

Published: June 25, 2018 
64 the environmental footprint of mainstream treatment facili65 ties. $^{12,13}$ Therefore, direct ammonia recovery from centrate 66 represents a good opportunity for wastewater nutrient 67 recovery.

68 Air stripping, ion exchange, and membrane processes have 69 been used for ammonia recovery from wastewater. ${ }^{14-17}$ 70 However, these technologies suffer from high energy demand 71 and/or require large quantities of chemicals for regener72 ation. ${ }^{2,18}$ Moreover, many of these technologies have low 73 selectivity. Besides, ammonium, phosphate, and other non74 nutrient ions (e.g., $\mathrm{Na}^{+}, \mathrm{Cl}^{-}$) are also recovered and mixed 75 with ammonium, which downgrades product quality, reduces 76 efficiency $^{13,19-23}$ and leads to scaling (e.g., struvite). ${ }^{21,22,24}$ In 77 this regard, electrochemical processes carry a good advantage 78 for product selection by utilizing low-cost electrons to realize 79 phase separation. ${ }^{10,20,25-28}$ In an electrochemical system, the 80 electrolysis of water produces hydroxide ions on the 81 cathode. $^{29,30}$ By separating the anode and cathode using an 82 ion exchange membrane (IEM), the high $\mathrm{pH}$ in the cathode 83 chamber can drive the conversion of ammonium ion $\left(\mathrm{NH}_{4}^{+}\right)$ 84 to ammonia $\left(\mathrm{NH}_{3}\right)$, which can be recovered using air stripping 85 or gas-permeable hydrophobic membranes. ${ }^{13,19,31}$ On the basis 86 of this hypothesis, Kuntke et al. first achieved ammonia 87 recovery $\left(3.29 \mathrm{gNH}_{3}-\mathrm{N} / \mathrm{m}^{2} / \mathrm{d}\right)$ from a membrane electrode 88 assembly (MEA) air cathode in a microbial fuel cell (MFC) via 89 gas diffusion. ${ }^{19}$ Though the air cathode was fabricated at low 90 cost, such gas diffusion structure was generally thick $(>1 \mathrm{~mm})$ 91 with low flexibility, and it could not withhold high water 92 pressure $(<30 \mathrm{kPa}),^{32-34}$ greatly limiting the potential for 93 scale-up. Soon afterward, a gas-permeable hydrophobic tubular 94 membrane was employed into the catholyte of a microbial 95 electrolysis cell (MEC) for ammonia recovery. ${ }^{26}$ This 96 integration not only achieved high rate ammonia recovery $97\left(19 \mathrm{gNH}_{3}-\mathrm{N} / \mathrm{m}^{2} / \mathrm{d}\right)$ but also greatly reduced system 98 complexity. Similar configurations with separated electrode 99 and membrane were also adopted in abiotic electrochemical 100 systems for ammonia recovery from urine with good 101 results. $^{28,35,36}$ However, in these processes with separated 102 electrode and membrane, the diffusion and/or migration of $103 \mathrm{NH}_{3} / \mathrm{OH}^{-}$from the cathode surface to the bulk for further 104 recovery was reported as a major rate limiting process, which 105 also governs cathodic potential losses. ${ }^{30,37}$

106 In this study, we developed a highly efficient membrane 107 electrode for active ammonia recovery from synthetic centrate. 108 The membrane electrode consisted of a hydrophilic thin-film 109 nickel layer deposited on a hydrophobic polypropylene (PP) 110 support layer. The central hypothesis is that by taking 111 advantage of the electric potential across the anode and 112 cathode during microbial electrolysis, ${ }^{29} \mathrm{NH}_{4}{ }^{+}$ions are driven 113 toward the hydrophilic nickel top layer on the cathode, and the 114 localized high $\mathrm{pH}$ on the cathode surface drives the conversion 115 of $\mathrm{NH}_{4}^{+}$to $\mathrm{NH}_{3}$, which can be readily volatilized and harvested 116 through the membrane, enabling high-efficiency recov117 ery. ${ }^{29,30,38}$ The novelty of this process comes from several 118 aspects: this integration utilizes the in situ local $\mathrm{pH}$ change on 119 the electrode surface, which reduces the loss of $\mathrm{OH}^{-} / \mathrm{NH}_{3}$ to 120 the bulk solution and thus boosts the ammonia recovery rate. 121 Reciprocally, ammonia recovery on the electrode surface 122 prevents the $\mathrm{OH}^{-} / \mathrm{NH}_{3}$ accumulation, and hence reduces 123 surface $\mathrm{pH}$ and the overpotential that subsequently boosts 124 current production. ${ }^{30}$ In addition to ammonia recovery, the 125 applied negative potential on the membrane electrode repels 126 negatively charged foulants and mitigates membrane foul- ing. ${ }^{39-41}$ More importantly, the hydrophobic support of the 127 membrane electrode prevents the permeation of any other 128 ions, thus guaranteeing high purity ammonia in the recovery 129 solution. Furthermore, the membrane electrode can be easily 130 fabricated at a low cost. To the best of our knowledge, this is 131 the first report of a flexible membrane electrode for ammonia 132 recovery. In addition to demonstrating the performance of the 133 system in terms of ammonia recovery, the underlying 134 mechanisms governing the reactions are illustrated.

135

\section{MATERIALS AND METHODS}

2.1. Materials and Chemicals. A commercial hydro- 136 phobic polypropylene (PP) membrane $(0.22-\mu \mathrm{m}$, Tisch 137 Scientific, North Bend, $\mathrm{OH}$ ) was used as the membrane 138 support in this study. Polyvinylidene fluoride (PVDF) and 139 multiwall carbon nanotubes (MWCNTs, outer diameter: 8-15 140 nm, length: 10-50 $\mu \mathrm{m}$ ) were purchased from Alfa Aesar 141 (Haverhill, MA) and CheapTubes (Brattleboro, VT), 142 respectively. All the chemicals were ACS grade and purchased 143 from Fisher Scientific (Waltham, MA). All working solutions 144 were prepared using Milli-Q water $(18.2 \mathrm{M} \Omega . \mathrm{cm})$ throughout 145 the study unless otherwise stated.

The feed solution was synthetic centrate ${ }^{13}$ that contained 147 the following $(\mathrm{mg} / \mathrm{L}): \mathrm{CH}_{3} \mathrm{COONa}, 2500 ; \mathrm{NaHCO}_{3}, 1500 ; 148$ $\mathrm{NH}_{4} \mathrm{Cl}, 4000 ; \mathrm{KH}_{2} \mathrm{PO}_{4}, 300 ; \mathrm{MgSO}_{4} \cdot 6 \mathrm{H}_{2} \mathrm{O}, 100$; and $\mathrm{CaCl}_{2}, 149$ 50. The total soluble chemical oxygen demand (COD), $\mathrm{NH}_{3}-150$ $\mathrm{N}, \mathrm{PO}_{4}-\mathrm{P}$, electrical conductivity, and $\mathrm{pH}$ of the synthetic 151 centrate were $2000 \pm 20 \mathrm{mg} / \mathrm{L}, 1000 \pm 10 \mathrm{mg} / \mathrm{L}, 200 \pm 5152$ $\mathrm{mg} / \mathrm{L}, 12.90 \pm 0.05 \mathrm{mS} / \mathrm{cm}$, and $7.51 \pm 0.05$, respectively. $\quad 153$

2.2. Membrane Preparation and Characterization. 154 The detailed preparation route of this membrane electrode can 155 be seen in Figure S1. In brief, $0.5 \mathrm{~g}$ of PVDF and $1.0 \mathrm{~g}$ of 156 MWCNT were dissolved/dispersed in $100 \mathrm{~g}$ of dimethylace- 157 tamide (DMAc) using a magnetic stirrer for $24 \mathrm{~h}$. After 60 min 158 of ultrasonication, the PVDF-MWCNT dispersion was 159 sprayed uniformly over the PP membrane support followed 160 by drying overnight in an oven at $50{ }^{\circ} \mathrm{C}$. The resulting 161 nanocomposite electrically conductive (EC) CNT/PP mem- 162 brane had MWCNT loadings of $0.29 \pm 0.04 \mathrm{mg} / \mathrm{cm}^{2}$. To 163 prepare the membrane electrode, electrodeposition was 164 performed in a reactor with a porous $\mathrm{Ni}$ foam as the anode 165 and the CNT/PP membrane as the cathode at a distance of 8166 $\mathrm{cm}$. The electrodeposition bath contained $150 \mathrm{mM} \mathrm{NiSO} \cdot 167$ $7 \mathrm{H}_{2} \mathrm{O}, 25 \mathrm{mM} \mathrm{NiCl} 2 \cdot 6 \mathrm{H}_{2} \mathrm{O}$, and $500 \mathrm{mM} \mathrm{H}_{3} \mathrm{BO}_{3}$ (at pH 2.00168 $\pm 0.05) .{ }^{42} \mathrm{~A}$ constant DC current of $0.2 \mathrm{~A}$ was applied on the 169 electrodes for $24 \mathrm{~h}$. The prepared membrane electrode was 170 rinsed in deionized water to remove $\mathrm{Ni}$ salts and unbound $\mathrm{Ni} 171$ residues before drying overnight at $50{ }^{\circ} \mathrm{C}$. The resulting 172 membrane electrode had a nickel loading of $7.36 \pm 0.10 \mathrm{mg} / 173$ $\mathrm{cm}^{2}$. The physical, electrochemical, and fouling properties of 174 the membrane electrode were characterized using scanning 175 electron microscopy (SEM), X-ray photoelectron spectroscopy 176 (XPS), X-ray diffraction (XRD), contact angle (CA) measure- 177 ments, conductivity probe, and linear sweep voltammetry 178 (LSV). ${ }^{38,39,43-47}$ Details of the measurements can be found in 179 Supporting Information (SI).

180

2.3. Reactor and Operations. Experiments were carried 181 out in an MEC reactor (Figure S2), with the electrodes 182 separated by a piece of cation exchange membrane $(25.5 \mathrm{~cm} \times 183$ $7.5 \mathrm{~cm}$, CMI-7000, Membrane International, NJ). Diamond- 184 shape polyester spacers were used in flow channels for 185 separation and promoting mass transfer. ${ }^{45,46}$ The anode 186 consisting of two carbon brushes $(5 \mathrm{~cm}$ in diameter $\times 50187$ 
$188 \mathrm{~cm}$ long) was inoculated with anaerobic sludge collected from 189 the Boulder Wastewater Treatment Plant and fed with the 190 synthetic centrate.

191 Different operations were tested in sequence in the same 192 reactor with the same anode, ${ }^{47}$ and both anolyte and catholyte 193 were the synthetic centrate. Three runs with different cathodes 194 and working conditions were operated. For each run with the 195 same operating condition, $7-11$ batch cycles were repeated. In 196 Run 1, a piece of fresh $\mathrm{Ni}$ foam was used as the cathode 197 without PP membrane or ammonia recovery (Figure S2C-1). 198 This was the baseline experiment in order to show the MEC 199 performance (i.e., current and $\mathrm{H}_{2}$ production) without 200 ammonia recovery, which was used to compare with the 201 results in Run 2 and Run 3 regarding the effects of ammonia 202 recovery on current and energy production. In Run 2, a same 203 piece of fresh $\mathrm{Ni}$ foam was used as the cathode but equipped 204 with a PP membrane for ammonia recovery using an external 205 acid solution recirculating independently on the opposite of 206 the cathode for ammonium capture (Figure S2C-2). In 207 addition to being compared with Run 1, Run 2 was also 208 used to simulate the conventional configuration with separated 209 electrode and membrane for ammonia recovery ${ }^{10,26,27,35,36}$ for 210 further comparisons with Run 3 with the new membrane 211 electrode, where the electrode and membrane were integrated. 212 In Run 3, a similar operation was used as in Run 2, except the 213 membrane electrode was employed as the cathode with nickel 214 layer facing the catholyte and membrane layer facing the 215 ammonia recovery solution (Figure S2C-3). To evaluate the 216 effects of active ammonia recovery on overpotential of the 217 membrane electrode, an operation similar to that of Run 3 218 (named as Membrane Electrode without Ammonia Recovery) 219 was used, except the ammonia recovery chamber was 220 hydraulically connected to the cathode chamber (Figure 221 S2C-4). Schematics and detailed explanations of these 222 configurations can be found in Section S2 of the SI. During 223 operations, the anolyte and catholyte were recirculated 224 separately with their respected reservoirs, and the flow rate 225 was $650 \mathrm{~mL} / \mathrm{min}$. For Run 2 and 3 with ammonia extraction, a 226 peristaltic pump at $100 \mathrm{~mL} / \mathrm{min}$ was used to circulate acid 227 solution $\left(1 \% \mathrm{H}_{2} \mathrm{SO}_{4}\right)$ between the ammonia recovery chamber 228 and an external reservoir $(1.0 \mathrm{~L})$. The gas products including $229 \mathrm{H}_{2}$ and $\mathrm{NH}_{3}$ were extracted into the acid solution for $\mathrm{NH}_{3}$ 230 adsorption into $\mathrm{H}_{2} \mathrm{SO}_{4}$ before collected in a 2.0-L bottle using 231 water displacement method. Solutions were replenished before 232 each batch. A voltage of $0.8 \mathrm{~V}$ was applied across the 233 electrodes, and the voltage across an external resistor $(R, 1 \Omega)$ 234 was measured every $10 \mathrm{~min}$ using a data acquisition system 235 (Keithley Instruments, Inc., Solon, $\mathrm{OH}) .{ }^{48}$ The whole 236 experiment was operated at room temperature $(22.0 \pm 0.5$ $\left.237^{\circ} \mathrm{C}\right)$.

238 2.4. Analysis. All samples were filtered through $0.45-\mu \mathrm{m}$ 239 cellulose membranes (Millipore) for $\mathrm{COD}, \mathrm{N}$, and $\mathrm{P}$ 240 measurements. COD was measured according to standard 241 methods described in detail by the American Public Health 242 Association. ${ }^{49} \mathrm{NH}_{3}-\mathrm{N}$ (TNT 832/831/830) and $\mathrm{PO}_{4}-\mathrm{P}$ 243 (TNT 846) were measured with $\mathrm{HACH}$ test tubes $(\mathrm{HACH}$, 244 Loveland, CO). Gas samples were analyzed using a gas 245 chromatograph (8610C, SRI Instruments) for $\mathrm{H}_{2}$ and $\mathrm{CH}_{4}$. All 246 samples were collected and analyzed in triplicate. ${ }^{50}$ The 247 ammonia recovery rate $\left(\mathrm{gNH}_{3}-\mathrm{N} / \mathrm{m}^{2} / \mathrm{d}\right)$ and specific energy 248 consumption $\left(\mathrm{kWh} / \mathrm{kgNH}_{3}-\mathrm{N}\right)$, cathodic $\mathrm{H}_{2}$ recovery $\left(r_{\text {cat }}\right.$, $249 \%), \mathrm{H}_{2}$ production rate $\left(Q \mathrm{~m}^{3}-\mathrm{H}_{2} / \mathrm{m}^{3} / \mathrm{d}\right)$ and energy 250 efficiency relative to electrical input $\left(\eta_{\mathrm{E}}, \%\right)$ were used to evaluate ammonia recovery and energy production from the 251 MEC (Section S12-13 in SI). ${ }^{47}$

\section{RESULTS AND DISCUSSION}

3.1. Membrane Electrode Characterization. Visual 253 images and SEM micrographs of the prepared membrane 254 electrode are shown in Figure S1, Figure 1, and Figure 5. XPS 255 fl

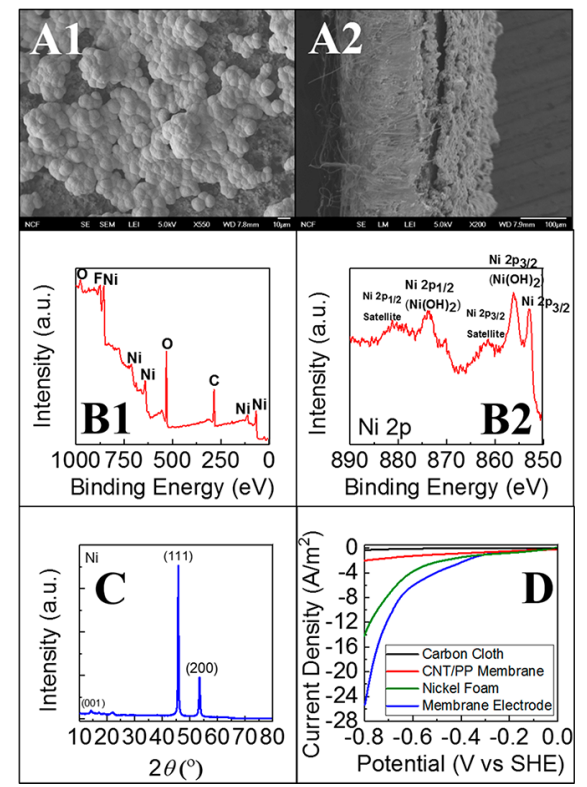

Figure 1. (A) SEM micrographs (1: top surface; 2: cross section), (B) XPS (1: survey spectrum; 2: high-resolution scan spectra of Ni 2p), (C) XRD of the prepared membrane electrode, and (D) linear sweep voltammetry (LSV) curves of the different cathodes. Current density was normalized to cathode effective project area $\left(7 \mathrm{~cm}^{2}\right)$.

analysis of the cauliflower-like thin film on the membrane 256 electrode surface (Figure 1B2) revealed relatively high peaks 257 for $\mathrm{Ni}(0)(852.7 \mathrm{eV}), \mathrm{Ni}(2+)(\mathrm{OH})_{2}(856 \mathrm{eV})$, and a weaker 258 peak of $\mathrm{Ni}(2+) \mathrm{O}(854 \mathrm{eV})$, indicating that the nickel layer was 259 a mixture of metallic and oxidized $\mathrm{Ni}^{51}$ The presence of 260 oxidized $\mathrm{Ni}$ on the membrane electrode was likely due to 261 partial oxidation by oxygen dissolved in the electrodeposition 262 bath or in air. ${ }^{42}$ The XRD pattern (Figure 1C) was consistent 263 with the typical profile of a nickel substrate with both 264 elemental and oxidized forms. ${ }^{47}$ Moreover, the prepared 265 membrane electrode can be bent $180^{\circ}$ with quick and natural 266 recovery, showing excellent flexibility compared to the 267 conventional nickel foam electrode, which was hardly 268 recovered after bent for only $30^{\circ}$ (Figure S5).

On the basis of these images, the thickness of the CNT and 270 nickel thin film on the membrane electrode were determined 271 to be $15 \pm 5 \mu \mathrm{m}$ and $25 \pm 5 \mu \mathrm{m}$, respectively. The sheet 272 resistivity and the corresponding electrical conductivity of the 273 CNT layer were $9.4 \pm 1.3 \times 10^{-4} \Omega . \mathrm{m}$ and $10.7 \mathrm{~S} / \mathrm{cm}, 274$ respectively, which were comparable to the results reported in 275 previous studies on CNT conductivity. ${ }^{38,52}$ The coated nickel 276 layer improved the electrical conductivity and reduced sheet 277 resistivity by 546 times, to $5871 \mathrm{~S} / \mathrm{cm}$ and $1.7 \pm 0.6 \times 10^{-6} 278$ $\Omega . m$, respectively. The membrane electrode showed excellent 279 electrochemical properties in hydrogen evolution reactions 280 (HER) (Figure 1D) with even more positive onset potential 281 than that of the nickel foam $(-0.3 \mathrm{~V}$ vs $-0.5 \mathrm{~V}) .{ }^{47,53}$ With the 282 decrease of the applied potential, the membrane electrode was 283 
284 more effective in current increase than the nickel foam. At the 285 cathodic potential of $-0.8 \mathrm{~V}$ (vs standard hydrogen electrode 286 (SHE)), the cathodic current of the membrane electrode was $28725.5 \mathrm{~A} / \mathrm{m}^{2}$, which was higher than that of the nickel foam (18.0 $288 \mathrm{~A} / \mathrm{m}^{2}$ ), suggesting that the membrane electrode has lower 289 overpotential and higher catalytic activity. Such advantage was 290 likely attributed to the crystalline composition of the coated 291 nickel layer (Figure 1B2), where $\mathrm{Ni}(\mathrm{OH})_{2}$ has been widely 292 reported as enhancing catalytic activities (i.e., better water 293 dissociation). ${ }^{54,55}$ This was further supported by LSV curves of 294 the nickel foam after electrolysis, which became rich in $295 \mathrm{Ni}(\mathrm{OH})_{2}$ and showed improved HER performance (Figure 296 S9B). Moreover, both the 2D structure and the gas 297 permeability by the hydrophobic support played important 298 role in higher performance, which facilitated gas separation on 299 the cathode surface and reduced the overpotential. ${ }^{31,56}$

300 3.2. Ammonia Recovery and Current Production.

301 Figure 2 shows the profiles of current production and rates of

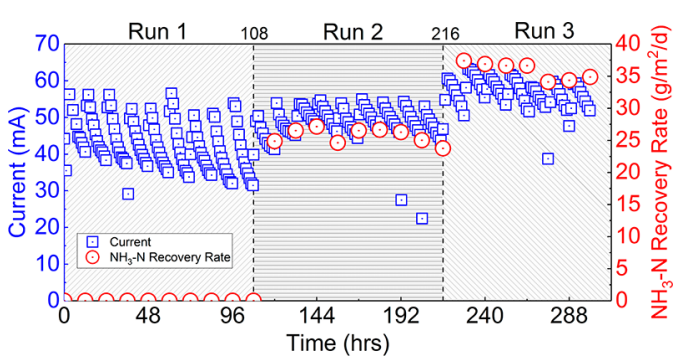

Figure 2. Time-course changes of current and ammonia recovery rate in the reactor. There were 9 batches in Run 1 (Ni foam without $\mathrm{NH}_{3}$ recovery) and Run 2 (Ni foam + PP membrane), and 7 batches in Run 3 (Ni decorated membrane electrode), with each batch lasting 12 h.

302 ammonia recovery during the different batch runs. A typical 303 batch profile started with rising current in the first few hours 304 due to the adaptation of the electroactive bacteria to the newly 305 replenished solutions. ${ }^{17,57}$ Once reaching the peak, the current 306 decreased gradually until the end of the batch. Run 1 and Run 3072 showed no significant differences in the peak current (54.4 \pm $3082.3 \mathrm{~mA}$ in Run 1 vs $55.8 \pm 1.9 \mathrm{~mA}$ in Run 2) during early 309 cycles, which was presumably due to the similar substrate 310 conditions (e.g., $\mathrm{COD}$ and $\mathrm{pH}$ ) at the beginning of each run. 311 However, over time, the catholyte $\mathrm{pH}$ in Run 1 (without 312 ammonia recovery) increased significantly from 7.51 to 9.34 313 due to $\mathrm{OH}^{-}$accumulation in the cathode chamber (Figure $314 \mathrm{~S} 10 \mathrm{~A})$. In response, the current dropped to $35.3 \pm 2.9 \mathrm{~mA}$ at 315 the end of the cycle. With ammonia recovery in Run 2, the 316 catholyte $\mathrm{pH}$ was maintained below 8.36 and the end current 317 was elevated to $44.9 \pm 1.9 \mathrm{~mA}$. The benefits of active ammonia 318 recovery were even more significant when the membrane 319 electrode was used in Run 3, during which the catholyte $\mathrm{pH}$ 320 stabilized at around 8.06. Its peak and end currents were 60.9 $321 \pm 1.6(\sim 11 \%$ higher than those of Run 1 and Run 2$)$ and 52.2 $322 \pm 1.8 \mathrm{~mA}(\sim 48.3 \%$ higher than Run 1 and $\sim 16.3 \%$ higher than 323 Run 2), respectively. In addition, the current profiles positively 324 correlated with ammonia recovery rate in Run 2 and Run 3, 325 which was consistent with previous studies. ${ }^{10,25,28,58}$ The 326 ammonia recovery rate and energy demand by the $\mathrm{Ni}$ 327 decorated membrane electrode in Run 3 were $36.2 \pm 1.2$ $328 \mathrm{gNH}_{3}-\mathrm{N} / \mathrm{m}^{2} / \mathrm{d}$ and $1.61 \pm 0.03 \mathrm{kWh} / \mathrm{kgNH}_{3}-\mathrm{N}$, respec329 tively, which were $40 \%$ faster $\left(25.7 \pm 1.2 \mathrm{gNH}_{3}-\mathrm{N} / \mathrm{m}^{2} / \mathrm{d}\right)$ and $33020 \%$ more energy efficient $\left(1.93 \pm 0.08 \mathrm{kWh} / \mathrm{kgNH}_{3}-\mathrm{N}\right)$ than those obtained in Run 2 with separated $\mathrm{Ni}$ foam and PP 331 membrane. In turn, the resulting higher current in Run 3332 corresponded with higher COD removal rates in the anode 333 chamber $(151 \pm 8 \mathrm{mgCOD} / \mathrm{L} / \mathrm{d})$, compared to those in Run 2334 $(119 \pm 20 \mathrm{mgCOD} / \mathrm{L} / \mathrm{d})$ and Run $1(106 \pm 24 \mathrm{mgCOD} / \mathrm{L} / 335$ d). Though the bioelectrochemical ammonia recovery rate 336 using the membrane electrode in Run $3\left(36.2 \pm 1.2 \mathrm{gNH}_{3}-\mathrm{N} / 337\right.$ $\mathrm{m}^{2} / \mathrm{d}$ ) was an order of magnitude lower than the reported 338 abiotic electrochemical systems $\left(50-300 \mathrm{gNH}_{3}-\mathrm{N} / \mathrm{m}^{2} / \mathrm{d}\right), 339$ the energy demand without considering $\mathrm{H}_{2}$ production using 340 the membrane electrode was up to $86 \%$ lower $(1.61 \pm 0.03$ vs 341 $\left.5-12 \mathrm{kWh} / \mathrm{kgNH}_{3}-\mathrm{N}\right)^{2,10,25,36,58}$ The membrane electrode in 342 Run 3 also showed very high COD rejection (>99\%) with the 343 COD in the recovery solution maintained below $10 \mathrm{mg} / \mathrm{L} . \quad 344$

The higher performance observed in Run 3 was believed to 345 be associated with the mutual benefits caused by the active 346 ammonia harvesting at the membrane electrode surface, which 347 alleviated the accumulation of $\mathrm{NH}_{3} / \mathrm{OH}^{-}$and reduced cathode 348 overpotential; $^{27,59}$ this, in turn, led to a higher current density 349 and ammonia recovery. According to the Nernst eq (Section 350 $\mathrm{S} 10$ in SI), increasing $\mathrm{pH}$ by one unit can lead to an increase of 351 overpotential by $59 \mathrm{mV}$. Therefore, the low catholyte $\mathrm{pH}$ in 352 Run 3 might have reduced the apparent overpotential by 17.7353 and $75.5 \mathrm{mV}$ compared to Run 2 and Run 1, respectively. To 354 further illustrate the effect of active ammonia recovery on the 355 overpotential, the membrane electrode was operated with and 356 without active ammonia recovery (Figure 3B). It was shown $357 \mathrm{f3}$

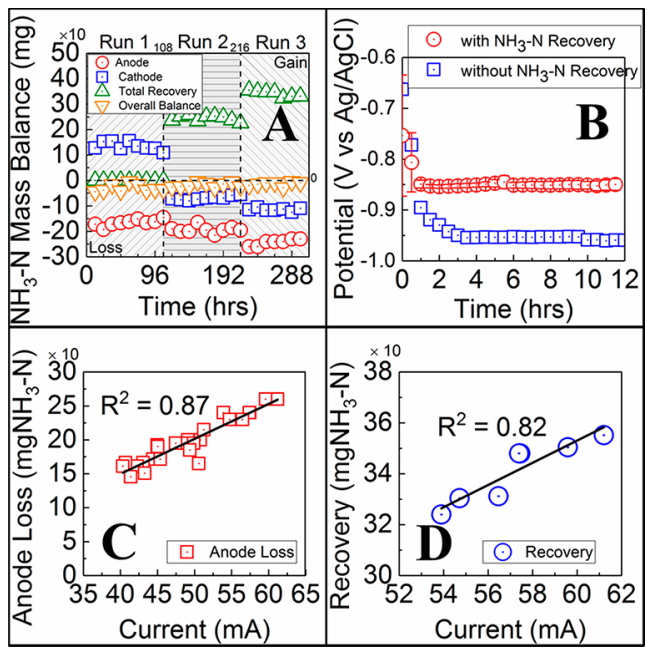

Figure 3. (A) Mass balance of $\mathrm{NH}_{3}-\mathrm{N}$ in the reactor during different runs; negative values mean mass loss; positive values mean mass gain; (B) time-course changes of cathode potential of the membrane electrode when operated with ammonia recovery (Run 3) and without ammonia recovery; (C) relating the current production to the $\mathrm{NH}_{3}-\mathrm{N}$ loss in the anolyte; (D) relating current production to the overall $\mathrm{NH}_{3}-\mathrm{N}$ recovery in Run 3 . The current in $\mathrm{C}$ and $\mathrm{D}$ is the average current of one batch $(12 \mathrm{~h})$.

that the overpotential difference was $0.11 \mathrm{~V}$, suggesting that at 358 a same current density, the actual $\mathrm{pH}$ on the electrode surface 359 with active ammonia recovery was 1.86 lower than that 360 operated without ammonia recovery. It is interesting to note 361 that the $\mathrm{pH}$ variance at the cathode surface was larger than that 362 of the bulk (1.28, Figure S10A). This indicated that the $\mathrm{pH} 363$ difference between the cathode surface and bulk solution 364 during ammonia recovery was comparatively lower than that 365 without ammonia recovery. The reduced $\mathrm{pH}$ gradient was due 366 


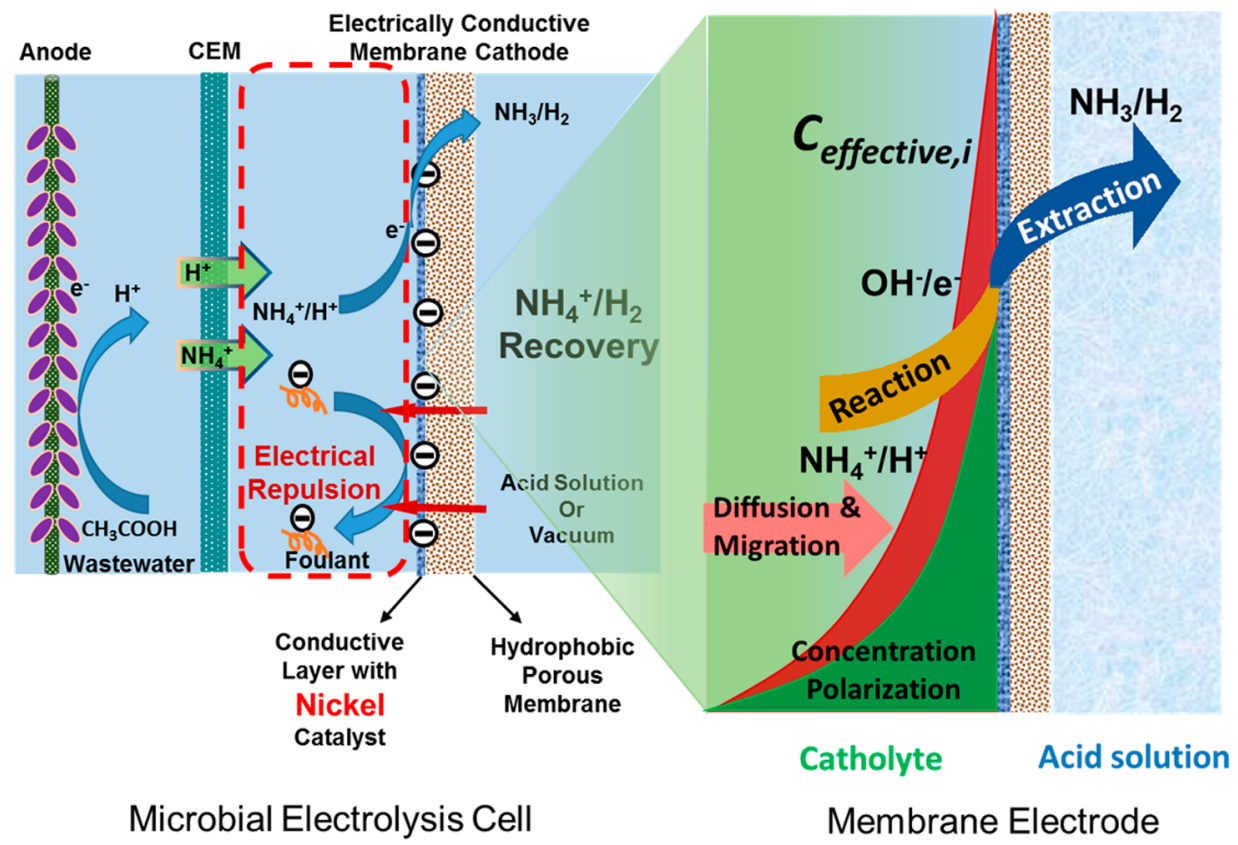

Figure 4. Conceptual diagram illustrating ammonia recovery mechanisms by the membrane electrode. Diffusion: Diffusion of $\mathrm{H}^{+}$and $\mathrm{NH}_{4}{ }^{+}$from the bulk solution to the cathode surface due to electro-adsorption. Reaction: Production of $\mathrm{H}_{2}, \mathrm{NH}_{3}, \mathrm{OH}^{-}$on the cathode surface by microbial electrolysis and high surface $\mathrm{pH}$. Extraction: Convection or extraction of $\mathrm{H}_{2}$ and $\mathrm{NH}_{3}$ from the cathode surface via the hydrophobic layer of the membrane electrode.

367 to the active ammonia harvesting, which could effectively 368 remove ammonia from the electrode surface thus altered the $369 \mathrm{NH}_{4}^{+} / \mathrm{NH}_{3}$ equilibrium and mitigated the accumulation of $370 \mathrm{NH}_{3} / \mathrm{OH}^{-}$on the electrode surface. The reduced $\mathrm{pH}$ on the 371 electrode surface hence mitigated cathodic potential losses and 372 might theoretically enhance the overall electrical efficiency by $3738.8 \%$. $^{30,60}$

\section{3.3. Ammonia Mass Balance and Mechanism for} 375 Improved Recovery. Figure 3 shows the overall mass balance 376 of the $\mathrm{NH}_{3}-\mathrm{N}$ present in different operating conditions. 377 Although for all runs good mass balances were achieved, the $378 \mathrm{NH}_{3}-\mathrm{N}$ transport in different runs varied significantly. Driven 379 by the current, $\mathrm{NH}_{4}{ }^{+}$was continuously transported from the 380 anolyte to the catholyte (Figure 3A) and the loss rate in the 381 anolyte was positively correlated with the current in the reactor 382 (Figure 3C). This is in agreement with our previous findings in 383 microbial resource recovery, in which ion transport was 384 determined by the current and by its relative abundance in 385 the solution. ${ }^{21}$ For Run 1 without ammonia harvesting, most of 386 the $\mathrm{NH}_{3}-\mathrm{N}$ loss in the anode chamber can be balanced with 387 the $\mathrm{NH}_{3}-\mathrm{N}$ increase in the cathode chamber. However, up to $38885 \mathrm{mg} \mathrm{NH} \mathrm{NH}_{3}-\mathrm{N}$ overall loss from the system was observed, 389 presumably due to the formation of struvite precipitate due to 390 increased cathode $\mathrm{pH}^{13,24}$ this is supported by the 391 corresponding loss of $\mathrm{PO}_{4}-\mathrm{P}$ (Figure S9).

392 In contrast, when ammonia harvesting was applied in Run 2 393 and Run 3, $\mathrm{NH}_{3}-\mathrm{N}$ concentrations dropped in both the 394 anolyte and catholyte. This simultaneous drop was due to the 395 ammonia harvesting from the cathode to the recovery solution 396 (Figure 3A). Overall, in Run 3, where the cathode chamber 397 was equipped with the membrane electrode (on which $\mathrm{NH}_{4}{ }^{+}-$ $398 \mathrm{~N}$ was electro-adsorbed and $\mathrm{pH}$ was much higher than the bulk $\left.399 \mathrm{pH}^{61,62}\right)$, the direct deprotonation and capture greatly 400 enhanced ammonia recovery by $40 \%$ as compared to Run 2 . 401 Benefiting from the active ammonia recovery using the membrane electrode, the local $\mathrm{pH}$ on the membrane electrode 402 surface was lowered, which reduced the cathodic potential loss 403 (Figure 3B) and enhanced current production (Figure 2). 404 Moreover, the catholyte bulk $\mathrm{pH}$ was also maintained below 405 8.06 during Run 3 (Figure S10A), which mitigated ammonia/ 406 phosphate precipitation (Figure S11).

407

Importantly, the ammonia recovery in Run 3 was directly 408 correlated with the current, as shown in Figure 3D. This is 409 likely because $\mathrm{NH}_{4}^{+}$ions served as proton shuttles during 410 operation, ${ }^{17,22,62}$ in which $\mathrm{NH}_{4}^{+}$ions carried protons to the 411 membrane electrode surface, and lost protons when they were 412 converted to $\mathrm{NH}_{3}$. In this study, the $\mathrm{NH}_{4}{ }^{+}$ions accounted for 413 $36.9 \pm 0.7 \%$ of all proton shuttles, which agreed with the 414 findings from a previous study. ${ }^{62}$

During MEC operation, the effective concentration 416 $\left(C_{\text {effective, }}\right)$ of a cation on the electrode surface can be 417 determined using the Nernst-Plank equation. ${ }^{63}$ Accordingly, 418 $\mathrm{NH}_{4}{ }^{+}$ions are pulled via diffusion and migration from the bulk 419 solution and accumulate at the electrode-solution interface, 420 where $\mathrm{NH}_{4}^{+}$concentration is higher than that in the bulk 421 (Figure 4). ${ }^{64}$ Because of water reduction during electrolysis on $422 \mathrm{f4}$ the MEC cathode, $\mathrm{OH}^{-}$accumulates on the electrode surface, 423 leading to localized $\mathrm{pH}$ increase and the deprotonation of 424 $\mathrm{NH}_{4}{ }^{+} \cdot{ }^{2930}$ Researchers previously employed hydrophobic 425 membranes for ammonia recovery from the catholyte, ${ }^{26,35} 426$ but the diffusion and/or migration of $\mathrm{NH}_{3} / \mathrm{OH}^{-}$from the 427 cathode surface to the bulk largely governed the cathodic 428 potential losses thus current production, which may reduce the 429 overall recovery performance. ${ }^{30}$ Moreover, buffer ions (e.g., 430 $\mathrm{HCO}_{3}{ }^{-}$and $\mathrm{HPO}_{4}{ }^{2-}$ ) can further reduce the efficiency by 431 countering catholyte $\mathrm{pH}$ change $\mathrm{e}^{30,37}$ and decreasing the 432 ammonia fraction. In this study, we took advantage of the 433 local $\mathrm{pH}$ increase on the membrane cathode surface to enable 434 in situ $\mathrm{NH}_{3}$ generation and separation, which mitigated 435 overpotential and eliminated the transport limitation of 436 
$437 \mathrm{NH}_{3} / \mathrm{OH}^{-}$from the cathode surface to the bulk for further 438 recovery. ${ }^{30}$ This approach enhanced the local generation and 439 consumption of $\mathrm{OH}^{-}$and promoted $\mathrm{NH}_{4}^{+}$transport from the 440 bulk toward the electrode to enable continuously high 441 efficiency $\mathrm{NH}_{3}$ harvesting (Figure 4). The active ammonia 442 recovery also reduced the electrode-solution interface $\mathrm{pH}$, 443 which reduced the overpotential associated with electrolysis 444 and enhanced current production. ${ }^{30}$

445 In addition to ammonia, hydrogen gas was also recovered 446 from the system. In Run 1 without ammonia recovery, the 447 system was operated similarly to a traditional two-chamber $448 \mathrm{MEC}$ with a nickel foam cathode, so $\mathrm{H}_{2}$ was stably produced at $4490.15 \pm 0.01 \mathrm{~m}^{3}-\mathrm{H}_{2} / \mathrm{m}^{3} / \mathrm{d}$ with a cathode efficiency of $100 \pm$ $4507 \%$. The cathodic efficiency was approximately $40 \%$ higher 451 than our previously reported result in a single-chamber 452 MEC. $^{47}$ It is interesting to note that ammonia recovery in 453 Run 2 reduced $\mathrm{H}_{2}$ production and cathode efficiency to $0.13 \pm$ $4540.02 \mathrm{~m}^{3}-\mathrm{H}_{2} / \mathrm{m}^{3} / \mathrm{d}$ and $75 \pm 9 \%$, respectively, though the 455 current was much higher as shown in Figure 2 and Table S3. 456 However, with active ammonia recovery using the membrane 457 electrode, Run 3 exhibited improved $\mathrm{H}_{2}$ production rate $(0.19$ $\left.458 \pm 0.01 \mathrm{~m}^{3}-\mathrm{H}_{2} / \mathrm{m}^{3} / \mathrm{d}\right)$ and cathode efficiency $(85 \pm 2 \%)$ 459 compared to Run 2. The variation of $\mathrm{H}_{2}$ production is believed 460 to be associated with ammonia recovery, thus $\mathrm{pH}$ and free 461 ammonia in the catholyte, which can greatly affect the activities 462 of hydrogen consumption microbes (e.g., sulfate-reducing 463 bacteria and methanogens). ${ }^{65,66}$ Detailed discussions can be 464 found in SI Section S13.

465 3.4. Low Fouling Behavior. Figure 5 shows the 466 membrane surface in Run 2 and membrane electrode in Run
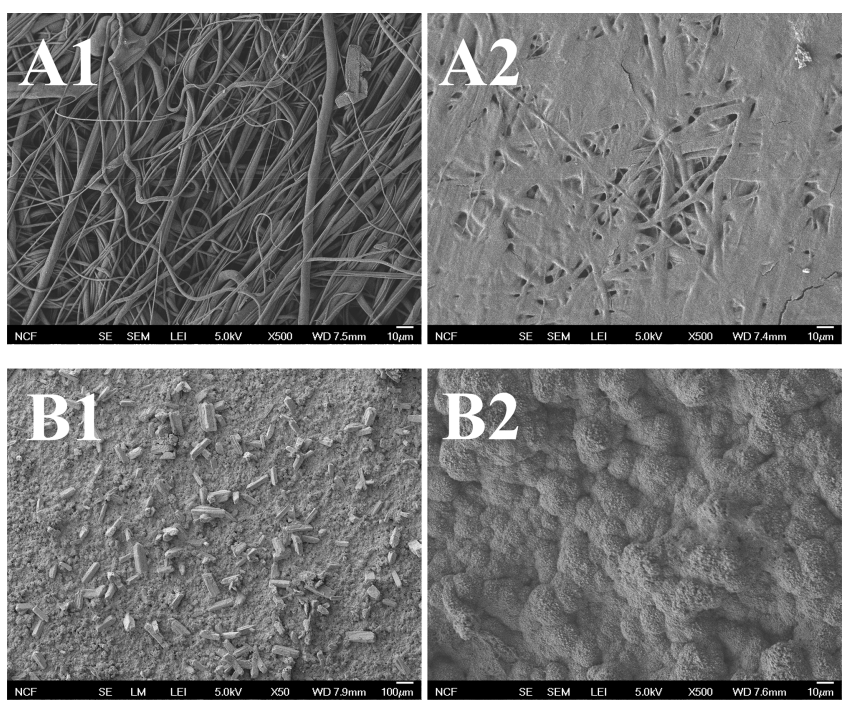

Figure 5. SEM images of the (A) PP membranes (1: pristine; 2: fouled) in Run 2 and (B) the membrane electrode (1: fouled; 2: after cleaning using $0.1 \% \mathrm{H}_{2} \mathrm{SO}_{4}$ for $15 \mathrm{~min}$ ) in Run 3 .

4673 following the ammonia harvesting experiments. The bare PP 468 membrane used in Run 2 displayed a yellowish color (Figure 469 S7C), and its SEM images with EDX analysis showed the 470 presence of organic fouling with significant crystal deposition 471 (Figure 5A). The deposited organics reduced the porosity of 472 the PP membrane (Figure 5A-2), ${ }^{67}$ which could reduce the 473 ammonia recovery efficiency. A more severe issue on PP 474 membrane in Run 2 can be membrane wetting, which can 475 result from organic matter depositing inside the membrane's pores. ${ }^{68}$ This can result in the acid leaking and reduced gas 476 separation. In contrast, the membrane electrode in Run 3 did 477 not suffer from organic fouling (Figure 5B-1 and Figure S7A- 478 2 ). This benefit may be a result of the negative potential on the 479 membrane electrode during operation, which repelled the 480 negatively charged organics and/or microbes. ${ }^{39,40}$ In addition, 481 the electrodeposited nickel thin layer greatly reduced the 482 roughness ( $\sim 35 \mathrm{~nm}$ vs $\sim 120 \mathrm{~nm}$ of the PP membrane, Figure 483 S3) and hydrophobicity (CA: $21.4 \pm 0.5^{\circ}$, Table S1) of the 484 composite membrane electrode, both of which help mitigate 485 organic fouling and biofouling. ${ }^{17,69}$ However, the membrane 486 electrode did show inorganic scaling (Figure S7A-2 and Figure 487 5B-1), which, based on XPS analysis, was found to be similar 488

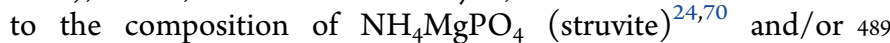
$\mathrm{Mg}_{3}\left(\mathrm{PO}_{4}\right)_{2}$ or $\mathrm{Ca}_{3}\left(\mathrm{PO}_{4}\right)_{2}{ }^{71,72}$ (Figure S8A). This was believed 490 to be attributed to the heterogeneous/surface crystallization on 491 the electrode surface, which was exacerbated by the $\mathrm{pH}$ change 492 due to electrolysis. ${ }^{70-72}$ During electrolysis, the negative 493 potential can promote the formation of an electric double 494 layer on the membrane surface ${ }^{73,74}$ Though the double layer 495 repels anions but also adsorbs cations (e.g., $\mathrm{NH}_{4}{ }^{+}$and $\mathrm{Mg}^{2+}$ ). ${ }^{74} 496$ Even though it has benefits of antiorganic fouling and 497 promoting ammonium transfer, the side effect is the increased 498 $\mathrm{pH}$ due to $\mathrm{OH}^{-}$accumulation, which could promote 499 crystallization. $^{71,72}$ Fortunately, inorganic scaling did not 500 significantly hinder the performance of the membrane 501 electrode, with current production dropped from 61.2 to 502 $56.5 \mathrm{~mA}$ (7.7\%), and ammonia recovery decreased from 37.4503 to $34.9 \mathrm{gNH}_{3}-\mathrm{N} / \mathrm{m}^{2} / \mathrm{d}(6.8 \%)$, respectively, in 7 batches 504 (Figure 2 and Figure 3A). Moreover, the deposited crystals 505 only appeared on the membrane surface and were easily 506 cleaned with $0.1 \% \mathrm{H}_{2} \mathrm{SO}_{4}$ (Figure 5B-2, Figure S7A-3 and 507 Figure S8A).

3.5. Implications and Outlook. The study demonstrated 509 in both reaction mechanisms and lab scale experiments that the 510 nickel-based membrane electrodes can achieve high rates of 511 electrochemically driven ammonia recovery. The layered 512 structure enabled both efficient catalysis on the hydrophilic 513 side and gas separation on the hydrophobic side, and the 514 negative potential and local $\mathrm{OH}^{-}$accumulation reduced 515 fouling and facilitated ammonia generation. In addition to 516 the data presented, we also found the membrane electrode 517 endured higher water pressure $(41.4 \pm 0.4 \mathrm{kPa})$ than 518 traditional air cathodes $(\sim 12 \mathrm{kPa}$ for PVDF based cathode, 519 and $0.18 \pm 0.02 \mathrm{~m}$ for PTFE and PDMS based cathodes). ${ }^{32} 520$ The high water enter pressure was able to prevent gas channel 521 flooding and grant the membrane electrode better scalability or 522 modulation (SI Section S5 ). Furthermore, the membrane 523 electrode was very thin $(<250$ Åm, Figure 1$)$ and flexible $\left(180^{\circ} 524\right.$ bend, Figure S5) and could be easily compiled into reactors, 525 either in the form of flat sheet or spiral-wound. Additionally, 526 the material cost of the membrane electrode $\left(<20 \$ / \mathrm{m}^{2}\right.$, SI 527 Section S6) was only a small fraction of the commercial nickel 528 foam $\left(160 \$ / \mathrm{m}^{2}\right)$, and the fabrication process was easy and 529 repeatable (SI Section S1). With many benefits discovered in 530 this proof-of-concept study, more work can be done in 531 optimizing the membrane electrode and improving system 532 performance. Long-term studies using actual high ammonium 533 substrates such as centrate, manure, or urine need to be 534 investigated, and scaling up and system integration need to be 535 performed. The process can also be optimized by modeling 536 ammonia recovery and catholyte $\mathrm{pH}$, all of which are key 537 factors affecting ammonia and energy recovery. 


\section{ASSOCIATED CONTENT}

\section{S Supporting Information}

541 The Supporting Information is available free of charge on the 542 ACS Publications website at DOI: 10.1021/acs.est.8b01349.

543 S1. Preparation Route of the Membrane Electrode; S2. $544 \quad$ Reactors and Configurations; S3. Surface Roughness; S4. 545 Surface Hydrophobicity/hydrophilicity; S5. Water Entry 546 Pressure and Flexibility; S6. Cost Analysis of the 547 Membrane Electrode; S7. Membrane Electrode and 548 Nickel Foam Before and After Electrolysis; S8. XPS 549 Spectra of the Membrane Electrode Before and After 550 Electrolysis; S9. LSV Scan of the Membrane Electrode 551 Before and After Electrolysis; S10. Effect of Active 552 Ammonia Harvest on Cathodic Potential; S11. Mass 553 Balance of $\mathrm{PO}_{4}-\mathrm{P} ; \mathrm{S} 12$. Ammonia Mass Balance $554 \quad$ Calculations; S13. Energy Production and Calculations. $555 \quad(\mathrm{PDF})$

\section{AUTHOR INFORMATION}

\section{Corresponding Author}

558 *Tel: +1 (303) 492 4137; Fax: +1 (303) 492 7317; E-mail: 559 zhiyong.ren@colorado.edu; Mail: Department of Civil, Envi560 ronmental, and Architectural Engineering, University of 561 Colorado Boulder, Boulder, CO, 80803, USA.

562 ORCID

563 Dianxun Hou: 0000-0002-0713-9553

564 Yifu Ding: 0000-0001-7779-7781

565 David Jassby: 0000-0002-2133-2536

566 Zhiyong Jason Ren: 0000-0001-7606-0331

567 Notes

568 The authors declare no competing financial interest.

\section{ACKNOWLEDGMENTS}

570 We thank Xiangchen Huo (Colorado School of Mines) for her 571 great assistance in membrane characterizations. We appreciate 572 the financial support from the US Department of Agriculture 573 (2017-67022-26135) and Office of Naval Research 574 (N000141612210).

\section{REFERENCES}

576 (1) Tilman, D.; Cassman, K. G.; Matson, P. A.; Naylor, R.; Polasky, $577 \mathrm{~S}$. Agricultural sustainability and intensive production practices. 578 Nature 2002, 418 (6898), 671-677.

579 (2) Xie, M.; Shon, H. K.; Gray, S. R.; Elimelech, M. Membrane580 based processes for wastewater nutrient recovery: technology, 581 challenges, and future direction. Water Res. 2016, 89, 210-221.

582 (3) Verstraete, W.; Van de Caveye, P.; Diamantis, V. Maximum use 583 of resources present in domestic "used water". Bioresour. Technol. 5842009,100 (23), 5537-5545.

585 (4) Rahman, M. M.; Salleh, M. A. M.; Rashid, U.; Ahsan, A.; 586 Hossain, M. M.; Ra, C. S. Production of slow release crystal fertilizer 587 from wastewaters through struvite crystallization - A review. Arabian J. 588 Chem. 2014, 7 (1), 139-155.

589 (5) Holloway, R. W.; Childress, A. E.; Dennett, K. E.; Cath, T. Y. 590 Forward osmosis for concentration of anaerobic digester centrate. 591 Water Res. 2007, 41 (17), 4005-4014.

592 (6) Karydis, M.; Chatzichristos, F. Coastal eutrophication in the 593 Mediterranean marine environment: A short review. Proc. Int. Conf. 594 Env Sc 2003, 426-430.

595 (7) Conley, D. J.; Paerl, H. W.; Howarth, R. W.; Boesch, D. F.; 596 Seitzinger, S. P.; Havens, K. E.; Lancelot, C.; Likens, G. E. 597 ECOLOGY Controlling Eutrophication: Nitrogen and Phosphorus. 598 Science 2009, 323 (5917), 1014-1015.
(8) McCarty, P. L.; Bae, J.; Kim, J. Domestic wastewater treatment 599 as a net energy producer-can this be achieved? Environ. Sci. Technol. 600 2011, 45 (17), 7100-7106.

601

(9) Hall, M. R.; West, J.; Sherman, B.; Lane, J.; de Haas, D. Long- 602 Term Trends and Opportunities for Managing Regional Water Supply 603 and Wastewater Greenhouse Gas Emissions. Environ. Sci. Technol. 604 2011, 45 (12), 5434-5440.

(10) Kuntke, P.; Sleutels, T. H. J. A.; Rodriguez Arredondo, M.; 606 Georg, S.; Barbosa, S. G.; ter Heijne, A.; Hamelers, H. V. M.; 607 Buisman, C. J. N. (Bio)electrochemical ammonia recovery: progress 608 and perspectives. Appl. Microbiol. Biotechnol. 2018, 102 (9), 3865- 609 3878 . 610

(11) Metcalf and Eddy. Wastewater Engineering: Treatment and 611 Resource Recovery; McGraw-Hill International, 2014.

(12) Ren, Z. J.; Umble, A. K. Water treatment: recover wastewater 613 resources locally. Nature 2016, 529 (7584), 25-25. 614

(13) Zou, S. Q.; Qin, M.; Moreau, Y.; He, Z. Nutrient-energy-water 615 recovery from synthetic sidestream centrate using a microbial 616 electrolysis cell - forward osmosis hybrid system. J. Cleaner Prod. 617 2017, 154, 16-25.

(14) Jorgensen, T. C.; Weatherley, L. R. Ammonia removal from 619 wastewater by ion exchange in the presence of organic contaminants. 620 Water Res. 2003, 37 (8), 1723-1728.

621

(15) Pronk, W.; Biebow, M.; Boller, M. Electrodialysis for recovering 622 salts from a urine solution containing micropollutants. Environ. Sci. 623 Technol. 2006, 40 (7), 2414-2420.

624

(16) Udert, K. M.; Wachter, M. Complete nutrient recovery from 625 source-separated urine by nitrification and distillation. Water Res. 626 2012, 46 (2), 453-464.

627

(17) Hou, D. X.; Lu, L.; Ren, Z. J. Microbial fuel cells and osmotic 628 membrane bioreactors have mutual benefits for wastewater treatment 629 and energy production. Water Res. 2016, 98, 183-189.

(18) Zhang, C. Y.; Ma, J. X.; He, D.; Waite, T. D. Capacitive 631 membrane stripping for ammonia recovery (CapAmm) from dilute 632 wastewaters. Environ. Sci. Technol. Lett. 2018, 5 (1), 43-49. 633

(19) Kuntke, P.; Smiech, K. M.; Bruning, H.; Zeeman, G.; Saakes, 634 M.; Sleutels, T. H. J. A.; Hamelers, H. V. M.; Buisman, C. J. N. 635 Ammonium recovery and energy production from urine by a 636 microbial fuel cell. Water Res. 2012, 46 (8), 2627-2636. 637 (20) Kuntke, P.; Sleutels, T. H. J. A.; Saakes, M.; Buisman, C. J. N. 638 Hydrogen production and ammonium recovery from urine by a 639 Microbial Electrolysis Cell. Int. J. Hydrogen Energy 2014, 39 (10), 640 $4771-4778$.

641

(21) Chen, X.; Sun, D.; Zhang, X.; Liang, P.; Huang, X. Novel self- 642 driven microbial nutrient recovery cell with simultaneous wastewater 643 purification. Sci. Rep. 2015, 5, 15744.

(22) Hou, D. X.; Lu, L.; Sun, D. Y.; Ge, Z.; Huang, X.; Cath, T. Y.; 645 Ren, Z. J. Microbial electrochemical nutrient recovery in anaerobic 646 osmotic membrane bioreactors. Water Res. 2017, 114, 181-188. 647

(23) Huggins, T. M.; Haeger, A.; Biffinger, J. C.; Ren, Z. J. Granular 648 biochar compared with activated carbon for wastewater treatment and 649 resource recovery. Water Res. 2016, 94, 225-232.

650

(24) Chen, X.; Zhou, H.; Zuo, K. C.; Zhou, Y.; Wang, Q. Y.; Sun, D. 651 Y.; Gao, Y. F.; Liang, P.; Zhang, X. Y.; Ren, Z. J.; Huang, X. Self- 652 sustaining advanced wastewater purification and simultaneous in situ 653 nutrient recovery in a novel bioelectrochemical system. Chem. Eng. J. 654 2017, 330, 692-697.

655

(25) Luther, A. K.; Desloover, J.; Fennell, D. E.; Rabaey, K. 656 Electrochemically driven extraction and recovery of ammonia from 657 human urine. Water Res. 2015, 87, 367-377.

(26) Kuntke, P.; Zamora, P.; Saakes, M.; Buisman, C. J. N.; 659 Hamelers, H. V. M. Gas-permeable hydrophobic tubular membranes 660 for ammonia recovery in bio-electrochemical systems. Environ. Sci- 661 Wat Res. 2016, 2 (2), 261-265.

(27) Sleutels, T. H. J. A.; Hoogland, B. J.; Kuntke, P.; ter Heijne, A.; 663 Buisman, C. J. N.; Hamelers, H. V. M. Gas-permeable hydrophobic 664 membranes enable transport of $\mathrm{CO} 2$ and $\mathrm{NH} 3$ to improve 665 performance of bioelectrochemical systems. Environ. Sci-Wat Res. 666 2016, 2 (4), 743-748. 
668 (28) Rodriguez Arredondo, M.; Kuntke, P.; Ter Heijne, A.; 669 Hamelers, H. V. M.; Buisman, C. J. N. Load ratio determines the 670 ammonia recovery and energy input of an electrochemical system. 671 Water Res. 2017, 111, 330-337.

672 (29) Kim, J. R.; Zuo, Y.; Regan, J. M.; Logan, B. E. Analysis of 673 ammonia loss mechanisms in microbial fuel cells treating animal 674 wastewater. Biotechnol. Bioeng. 2008, 99 (5), 1120-1127.

675 (30) Popat, S. C.; Ki, D.; Rittmann, B. E.; Torres, C. I. Importance 676 of OH- transport from cathodes in microbial fuel cells. ChemSusChem 677 2012, 5 (6), 1071-1079.

678 (31) Lu, L.; Hou, D.; Wang, X.; Jassby, D.; Ren, Z. J. Active $\mathrm{H}_{2}$ 679 harvesting prevents methanogenesis in microbial electrolysis cells. 680 Environ. Sci. Technol. Lett. 2016, 3 (8), 286-290.

681 (32) Yang, W. L.; He, W. H.; Zhang, F.; Hickner, M. A.; Logan, B. E. 682 Single-step fabrication using a phase inversion method of poly683 (vinylidene fluoride) (PVDF) activated carbon air cathodes for 684 microbial fuel cells. Environ. Sci. Technol. Lett. 2014, 1 (10), 416-420. 685 (33) Dong, H.; Yu, H. B.; Wang, X. Catalysis Kinetics and Porous 686 Analysis of Rolling Activated Carbon-PTFE Air-Cathode in Microbial 687 Fuel Cells. Environ. Sci. Technol. 2012, 46 (23), 13009-13015.

688 (34) He, W. H.; Liu, J.; Li, D.; Wang, H. M.; Qu, Y. P.; Wang, X.; 689 Feng, Y. J. The electrochemical behavior of three air cathodes for 690 microbial electrochemical system (MES) under meter scale water 691 pressure. J. Power Sources 2014, 267, 219-226.

692 (35) Zamora, P.; Georgieva, T.; Ter Heijne, A.; Sleutels, T. H. J. A.; 693 Jeremiasse, A. W.; Saakes, M.; Buisman, C. J. N.; Kuntke, P. Ammonia 694 recovery from urine in a scaled-up microbial electrolysis cell. J. Power 695 Sources 2017, 356, 491-499.

696 (36) Tarpeh, W. A.; Barazesh, J. M.; Cath, T. Y.; Nelson, K. L. 697 Electrochemical stripping to recover nitrogen from source-separated 698 urine. Environ. Sci. Technol. 2018, 52 (3), 1453-1460.

699 (37) Torres, C. I.; Lee, H. S.; Rittmann, B. E. Carbonate species as $700 \mathrm{OH}(-)$ carriers for decreasing the ph gradient between cathode and 701 anode in biological fuel cells. Environ. Sci. Technol. 2008, 42 (23), $7028773-8777$.

703 (38) Tang, L.; Iddya, A.; Zhu, X.; Dudchenko, A. V.; Duan, W.; 704 Turchi, C.; Vanneste, J.; Cath, T. Y.; Jassby, D. Enhanced flux and 705 electrochemical cleaning of silicate scaling on carbon nanotube-coated 706 membrane distillation membranes treating geothermal brines. ACS 707 Appl. Mater. Interfaces 2017, 9 (44), 38594-38605.

708 (39) Dudchenko, A. V.; Rolf, J.; Russell, K.; Duan, W. Y.; Jassby, D. 709 Organic fouling inhibition on electrically conducting carbon nano710 tube-polyvinyl alcohol composite ultrafiltration membranes. J. Membr. 711 Sci. 2014, 468, 1-10.

712 (40) Ronen, A.; Duan, W. Y.; Wheeldon, I.; Walker, S.; Jassby, D. 713 Microbial attachment inhibition through low-voltage electrochemical 714 reactions on electrically conducting membranes. Environ. Sci. Technol. 715 2015, 49 (21), 12741-12750.

716 (41) Huang, Z.; Gong, A.; Hou, D. X.; Hu, L. B.; Ren, Z. J. A 717 conductive wood membrane anode improves effluent quality of 718 microbial fuel cells. Environ. Sci-Wat Res. 2017, 3 (5), 940-946.

719 (42) Hrapovic, S.; Manuel, M. F.; Luong, J. H. T.; Guiot, S. R.; 720 Tartakovsky, B. Electrodeposition of nickel particles on a gas diffusion 721 cathode for hydrogen production in a microbial electrolysis cell. Int. J. 722 Hydrogen Energy 2010, 35 (14), 7313-7320.

723 (43) Hou, D. X.; Feng, H.; Zhang, J. B.; Dong, S. S.; Zhou, D. D.; $724 \mathrm{Lim}, \mathrm{T}$. T. Preparation, characterization and performance of a novel 725 visible light responsive spherical activated carbon-supported and $726 \mathrm{Er} 3+$ :YFeO3-doped TiO2 photocatalyst. J. Hazard. Mater. 2012, 199, 727 301-308.

728 (44) Hou, D. X.; Goei, R.; Wang, X. P.; Wang, P. H.; Lim, T. T. 729 Preparation of carbon-sensitized and $\mathrm{Fe}-\mathrm{Er}$ codoped $\mathrm{TiO} 2$ with 730 response surface methodology for bisphenol A photocatalytic 731 degradation under visible-light irradiation. Appl. Catal., B 2012, 126, $732 \quad 121-133$.

733 (45) Huang, Z.; Lu, L.; Cai, Z.; Ren, Z. J. Individual and competitive 734 removal of heavy metals using capacitive deionization. J. Hazard. 735 Mater. 2016, 302, 323-331.
(46) Zhang, M. M.; Hou, D. X.; She, Q. H.; Tang, C. Y. Y. Gypsum 736 scaling in pressure retarded osmosis: experiments, mechanisms and 737 implications. Water Res. 2014, 48, 387-395.

(47) Lu, L.; Hou, D. X.; Fang, Y. F.; Huang, Y. P.; Ren, Z. J. Nickel 739 based catalysts for highly efficient $\mathrm{H}_{2}$ evolution from wastewater in 740 microbial electrolysis cells. Electrochim. Acta 2016, 206, 381-387. 741

(48) Chookaew, T.; Prasertsan, P.; Ren, Z. J. Two-stage conversion 742 of crude glycerol to energy using dark fermentation linked with 743 microbial fuel cell or microbial electrolysis cell. New Biotechnol. 2014, 744 31 (2), 179-184. 745

(49) American Public Health Association. Standard Methods for the 746 Examination of Water and Wastewater, 20th ed.; APHA, 1998.

(50) Wang, H. M.; Davidson, M.; Zuo, Y.; Ren, Z. Y. Recycled tire 748 crumb rubber anodes for sustainable power production in microbial 749 fuel cells. J. Power Sources 2011, 196 (14), 5863-5866.

750

(51) Grden, M.; Alsabet, M.; Jerkiewicz, G. Surface science and 751 electrochemical analysis of nickel foams. ACS Appl. Mater. Interfaces 752 2012, 4 (6), 3012-3021.

(52) de Lannoy, C. F.; Jassby, D.; Davis, D. D.; Wiesner, M. R. A 754 highly electrically conductive polymer-multiwalled carbon nanotube 755 nanocomposite membrane. J. Membr. Sci. 2012, 415, 718-724. 756

(53) Luo, J. S.; Im, J. H.; Mayer, M. T.; Schreier, M.; Nazeeruddin, 757 M. K.; Park, N. G.; Tilley, S. D.; Fan, H. J.; Gratzel, M. Water 758 photolysis at $12.3 \%$ efficiency via perovskite photovoltaics and Earth- 759 abundant catalysts. Science 2014, 345 (6204), 1593-1596. 760 (54) Subbaraman, R.; Tripkovic, D.; Strmcnik, D.; Chang, K. C.; 761 Uchimura, M.; Paulikas, A. P.; Stamenkovic, V.; Markovic, N. M. 762 Enhancing hydrogen evolution activity in water splitting by tailoring 763 $\mathrm{Li}+\mathrm{-Ni}(\mathrm{OH})(2)-\mathrm{Pt}$ interfaces. Science 2011, 334 (6060), 1256-1260. 764 (55) Shalom, M.; Ressnig, D.; Yang, X. F.; Clavel, G.; Fellinger, T. 765 P.; Antonietti, M. Nickel nitride as an efficient electrocatalyst for 766 water splitting. J. Mater. Chem. A 2015, 3 (15), 8171-8177. 767

(56) Zhang, Y. M.; Merrill, M. D.; Logan, B. E. The use and 768 optimization of stainless steel mesh cathodes in microbial electrolysis 769 cells. Int. J. Hydrogen Energy 2010, 35 (21), 12020-12028. 770

(57) Feng, Y.; Wang, X.; Logan, B. E.; Lee, H. Brewery wastewater 771 treatment using air-cathode microbial fuel cells. Appl. Microbiol. 772 Biotechnol. 2008, 78 (5), 873-880.

(58) Desloover, J.; Abate Woldeyohannis, A.; Verstraete, W.; Boon, 774 N.; Rabaey, K. Electrochemical Resource Recovery from Digestate to 775 Prevent Ammonia Toxicity during Anaerobic Digestion. Environ. Sci. 776 Technol. 2012, 46 (21), 12209-12216.

(59) Merrill, M. D.; Logan, B. E. Electrolyte effects on hydrogen 778 evolution and solution resistance in microbial electrolysis cells. J. 779 Power Sources 2009, 191 (2), 203-208.

(60) Jeremiasse, A. W.; Hamelers, H. V. M.; Kleijn, J. M.; Buisman, 781 C. J. N. Use of biocompatible buffers to reduce the concentration 782 overpotential for hydrogen evolution. Environ. Sci. Technol. 2009, 43783 (17), 6882-6887.

(61) Cord-Ruwisch, R.; Law, Y.; Cheng, K. Y. Ammonium as a 785 sustainable proton shuttle in bioelectrochemical systems. Bioresour. 786 Technol. 2011, 102 (20), 9691-9696.

(62) Liu, Y.; Qin, M.; Luo, S.; He, Z.; Qiao, R. Understanding 788 ammonium transport in bioelectrochemical systems towards its 789 recovery. Sci. Rep. 2016, 6, 22547.

(63) Kim, T.; Dykstra, J. E.; Porada, S.; van der Wal, A.; Yoon, J.; 791 Biesheuvel, P. M. Enhanced charge efficiency and reduced energy use 792 in capacitive deionization by increasing the discharge voltage. J. 793 Colloid Interface Sci. 2015, 446, 317-326.

(64) Perez, C. A. R.; Demirer, O. N.; Clifton, R. L.; Naylor, R. M.; 795 Hidrovo, C. H. Macro analysis of the electro-adsorption process in 796 low concentration nacl solutions for water desalination applications. J. 797 Electrochem. Soc. 2013, 160 (3), E13-E21.

(65) Hansen, K. H.; Angelidaki, I.; Ahring, B. K. Anaerobic digestion 799 of swine manure: Inhibition by ammonia. Water Res. 1998, 32 (1), 5- 800 12.

(66) Gutierrez, O.; Park, D.; Sharma, K. R.; Yuan, Z. Q. Effects of 802 long-term $\mathrm{pH}$ elevation on the sulfate-reducing and methanogenic 803 
804 activities of anaerobic sewer biofilms. Water Res. 2009, 43 (9), 25498052557.

806 (67) Zarebska, A.; Amor, A. C.; Ciurkot, K.; Karring, H.; Thygesen, 807 O.; Andersen, T. P.; Hagg, M. B.; Christensen, K. V.; Norddahl, B. 808 Fouling mitigation in membrane distillation processes during 809 ammonia stripping from pig manure. J. Membr. Sci. 2015, 484, $810119-132$.

811 (68) Goh, S. W.; Zhang, J. S.; Liu, Y.; Fane, A. G. Fouling and 812 wetting in membrane distillation (MD) and MD-bioreactor (MDBR) 813 for wastewater reclamation. Desalination 2013, 323, 39-47.

814 (69) Tiraferri, A.; Kang, Y.; Giannelis, E. P.; Elimelech, M. Highly 815 hydrophilic thin-film composite forward osmosis membranes 816 functionalized with surface-tailored nanoparticles. ACS Appl. Mater. 817 Interfaces 2012, 4 (9), 5044-5053.

818 (70) Cusick, R. D.; Logan, B. E. Phosphate recovery as struvite 819 within a single chamber microbial electrolysis cell. Bioresour. Technol. 820 2012, 107, 110-115.

821 (71) An, J.; Li, N.; Wan, L. L.; Zhou, L.; Du, Q.; Li, T.; Wang, X. 822 Electric field induced salt precipitation into activated carbon air823 cathode causes power decay in microbial fuel cells. Water Res. 2017, 824 123, 369-377.

825 (72) Lei, Y.; Song, B. N.; van der Weijden, R. D.; Saakes, M.; 826 Buisman, C. J. N. Electrochemical induced calcium phosphate 827 precipitation: importance of local pH. Environ. Sci. Technol. 2017, 82851 (19), 11156-11164.

829 (73) Forrestal, C.; Xu, P.; Ren, Z. Y. Sustainable desalination using a 830 microbial capacitive desalination cell. Energy Environ. Sci. 2012, 5 (5), $8317161-7167$.

832 (74) Duan, W. Y.; Dudchenko, A.; Mende, E.; Flyer, C.; Zhu, X. B.; 833 Jassby, D. Electrochemical mineral scale prevention and removal on 834 electrically conducting carbon nanotube - polyamide reverse osmosis 835 membranes. Environ. Sci-Proc. Imp 2014, 16 (6), 1300-1308. 